\title{
Munnskylling med klorheksidin for å forebygge pneumoni
}

\author{
Lokal applikasjon av klorheksidin i munnhulen motvirker akkumulering \\ av patogene mikrober i munnen. Dermed kan risikoen for spredning \\ av slike mikrober til lunger og andre organer reduseres. I dette grense- \\ området mellom odontologi og medisin er samarbeid viktig.
}

Se også kunnskapsprøve på www.tidsskriftet.no/quiz

\section{Per Løkken}

per.lokken@odont.uio.no

Seksjon for odontologisk farmakologi

og farmakoterapi

Universitetet i Oslo

Postboks 1119 Blindern

0317 Oslo

\section{Ingar Olsen}

Institutt for oral biologi

Universitetet i Oslo

\section{Olav Spigset}

Avdeling for klinisk farmakologi

St. Olavs hospital

og

Institutt for laboratoriemedisin,

barne- og kvinnesykdommer

Norges teknisk-naturvitenskapelige universitet

Nordiske forskere viste i 1970 -årene at munnskylling med klorheksidin gir opptil $90 \%$ reduksjon i mengden orale mikroorganismer. Omfattende bruk av klorheksidin innen odontologien har dokumentert at det er et effektivt og velegnet middel mot infeksjoner i munnhulen (1). Det er økende erkjennelse av at klorheksidin fortjener større oppmerksomhet og anvendelse også innen generell medisin, for å hindre spredning av patogene mikrober fra munnhulen til lunger og andre organer. Slike munnhulemikrober kan føre til blant annet endokarditt og luftveisinfeksjoner som pneumoni og infeksiøse eksaserbasjoner ved kronisk obstruktiv lungesykdom (fig 1) (2-6).

Hensikten med denne artikkelen er å rette oppmerksomheten mot munnhulens rolle som reservoar for patogene mikroorganismer og klorheksidinets evne til å forebygge og redusere spredning av slike mikrober fra munnhulen til lunger og andre organer. Vi vil også diskutere hvorvidt dekontaminering av munnhulen med klorheksidin kan tenkes å forebygge risikoen for sekundære bakterielle pneumonier ved influensa.

\section{Materiale og metode}

Grunnlaget for artikkelen er et ikke-systematisk litteratursøk i PubMed med et skjønns- messig utvalg av artikler basert på vår erfaring innen feltet.

\section{Dentalt plakk}

Dentalt plakk er en biofilm med mikroorganismer i en klebrig polysakkaridmasse. Det kan belegge både supra- og subgingivale tannflater. Slikt plakk kan også finnes på tungen, på slimhinnene i munnen og i pharynx samt på tannproteser og implantater. Plakkets mikroflora og mengde påvirkes av faktorer som munnhygiene, spyttsekresjon og lokalt immunforsvar. Manglende eller dårlig munnhygiene øker plakkmengden og plakkets patogenisitet, ikke minst hos pasienter med sviktende spyttsekresjon.

Hos friske individer domineres floraen i munnhule og svelg av viridansstreptokokker, haemophilusarter og anaerobe bakterier. Hos medisinsk kompromitterte, for eksempel respiratorpasienter, endres floraen raskt til gramnegative bakterier, stafylokokker og

Den mest effektive og beste form for plakkontroll er regelmessig mekanisk rengjøring av tenner og munnhule, for eksempel med børsting. Antiseptika er et supplerende hjelpemiddel eller alternativ. Blant disse er klorheksidin oftest best og mest effektivt.

Mens klorheksidin hindrer nydanning og akkumulering av plakk, er det omdiskutert og tvilsomt om allerede etablert plakk fjernes. Den antimikrobielle effekten av klorheksidin optimaliseres dersom det før applikasjon foretas fjerning av tilstedeværende plakk, for eksempel med tannbørsting, bruk av tannpirkere eller tupfere.

\section{Klorheksidin som munnhuleantiseptikum}

En viktig egenskap ved klorheksidin er stoffets evne til å binde seg til tenner, plakk og munnslimhinne. Dermed dannes det depoter hvorfra midlet kontinuerlig frigjøres, slik at den lokale antimikrobielle effekten opprettholdes i flere timer (1). Klorheksidin hemmer og reduserer plakkdanning i munnhulen mer effektivt enn andre aktuelle antiseptika. gjærsopp.
Stoffet absorberes praktisk talt ikke fra munnhulen eller mage-tarm-kanalen.

Klorheksidin har et bredt antibakterielt spektrum. Stoffet har også effekt på visse sopper og virus, men påvirker ikke mykobakterier eller bakteriesporer. Det har særlig god effekt mot grampositive bakterier, inklusive multiresistente patogener som meticillinresistente gule stafylokokker (MRSA) og vankomycinresistente enterokokker (VRE).

Fordi klorheksidin gir en så kraftig reduksjon av plakkdanningen og mikrobemengden i munnhulen $(90 \%)$ har det vært stilt spørsmål ved om stoffet kan fremkalle forandringer i mikrobenes resistens og økologi. Allerede i 1976 ble det rapportert at dette ikke er noe stort klinisk problem (7). I de senere år er det påvist stammer av MRSA (qacA/B) med 2-4 ganger økte MIC-verdier for klorheksidin (8). Det er viktig kontinuerlig å overvåke forekomsten av slik lavnivåresistens $(6,8)$.

Klorheksidin har få bivirkninger. Forbigående smaksforstyrrelser er vanligst, og noen får misfarging av tenner og tunge etter 1-2 ukers bruk. Svie og munnslimhinnedeskvamasjoner forekommer iblant. Dette kan motvirkes ved å fortynne løsningen med vann. Allergiske reaksjoner er rapportert en sjelden gang.

\section{Dokumenterte effekter}

Pneumoni hos pasienter som behandles i respirator, er den hyppigst forekommende infeksjonen i intensivavdelinger. Den skyldes hovedsakelig aspirasjon av orofaryngeale mikrober, som deretter formerer seg $\mathrm{i}$ lungevevet. Metaanalyser har vist at risikoen for respiratorassosiert pneumoni reduseres til omtrent halvparten med klorheksi$\operatorname{din}(3,6)$, fra en forekomst på 10-20\% ned til anslagsvis $5-10 \%$. I en nyere oversiktsartikkel anbefales det at oral applikasjon av

\section{Hovedbudskap}

- Klorheksidin munnskyllevæske kan redusere risikoen for spredning av orale patogene mikrober til lunger og andre organer

- Klorheksidin kan være et supplement eller et alternativ til mekanisk munnhygiene når dette er vanskelig å gjennomføre

- Jo sykere pasienten er, desto viktigere er munnstellet 


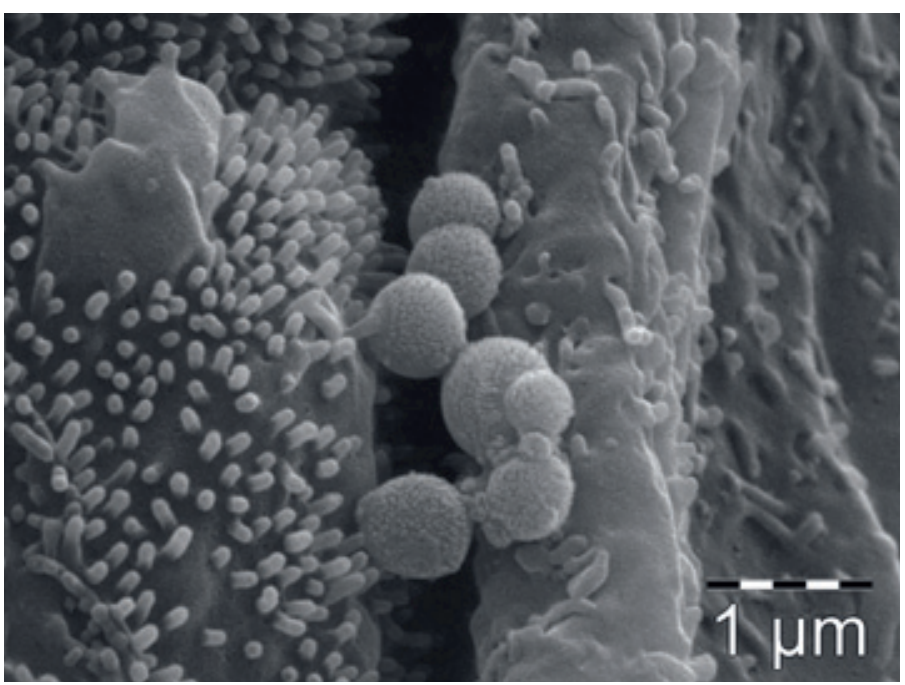

Figur 1 Elektronmikroskopisk bilde av små kokker, trolig orale Veillonella, på lungeepitel hos en pasient med kronisk obstruktiv lungesykdom. Gjengitt med tillatelse fra Inga Leuckfeld

klorheksidin bør inngå som ett av tiltakene for å forebygge respiratorassosiert pneumoni (9).

I to studier har man undersøkt effekten av munnskylling med klorheksidin under og etter åpen hjertekirurgi, inkludert tiden etter ekstubasjon $(2,4)$. I den ene studien var forekomsten av nedre luftveisinfeksjoner $3 \%$ i klorheksidingruppen og $9 \%$ i placebogruppen (2), i den andre (4) var sifrene henholdsvis $9 \%$ og $16 \%$ (4). Man påviste også en reduksjon i forekomsten av andre infeksjoner, kortere liggetid og lavere mortalitet.

\section{Andre mulige indikasjoner}

Studiene med intensivpasienter i respirator og med pasienter etter åpen hjertekirurgi viser at oral applikasjon av klorheksidin kan bidra til å forebygge utvikling av alvorlige infeksjoner.

\section{Ramme 1}

\section{Praktisk bruk av klorheksidin munnskyllevæske}

$0,2 \%$ klorheksidinoppløsning er mest brukt i Norge. Skylling kan gjennomføres med $10 \mathrm{ml}$ (20 mg klorheksidin) i minst et halvt minutt to ganger daglig

Noen pasienter kan få svie og munnslimhinnedeskvamasjon ved bruk av $0,2 \%$-løsning. Dette forsvinner vanligvis om man går over til $0,1 \%$ (fortynnes med vann fra springen)

Før skyllingen bør munnhulen rengjøres mekanisk. Dersom tannkrem brukes, bør den ikke inneholde anioniske stoffer som laurylsulfat, da dette kan redusere den antimikrobielle effekten av klorheksidin

Hos pasienter som ikke er i stand til å skylle, og hos barn under tre år, kan klorheksidin appliseres med en godt fuktet tupfer eller vattpinne
Klorheksidin kan også være aktuelt i andre sammenhenger når vanlig munnhygiene er vanskelig, for eksempel ved vanlige infeksiøse barnesykdommer med oppkast. Også for fysisk og/eller mentalt handikappede kan bruk av klorheksidin være aktuelt. En norsk studie viste allerede i 1974 at oral applikasjon med klorheksidin hos alvorlig syke barn reduserte barnas lidelser og motvirket spredning av trøske fra munnhulen (10). Generelt gjelder at jo sykere pasienten er, desto viktigere er munnstellet.

Vi har ikke funnet noen kontrollerte kliniske undersøkelser som viser at oral applikasjon av klorheksidin reduserer risikoen for sekundære bakterielle pneumonier hos influensapasienter. Det kan ha flere årsaker. Opplegg og utførelse av slike studier er tidsog ressurskrevende. Patenttiden for klorheksidin har løpt ut, slik at en eventuell fortjeneste for legemiddelindustrien vil være lav. Til tross for mangel på kontrollerte undersøkelser kan det likevel være relevant å vurdere munnskyllinger med klorheksidin ved influensa, særlig hos eldre. Klorheksidin har god effekt mot grampositive bakterier, som $S$ aureus, og det er også vist $i$ in vitro-studier at midlet har en viss antiviral effekt mot Herpes simplex-, cytomegalo-, influensa A-, parainfluensa- og hepatitt B-virus (11).

I en randomisert japansk studie ble effekten av munnstell hos eldre sykehjemspasienter gjennom to år studert (12). Halvparten fikk intensivert grundig mekanisk munnstell, mens den andre gruppen ikke ble tilbudt noe spesielt munnstell. Pneumoni ble diagnostisert hos 34 av de 182 pasientene (19\%) som ikke fikk munnstell og hos 21 av de $184(11 \%)$ som fikk $(\mathrm{p}<0,05)$. Av pasientene som fikk pneumoni, døde 30 i gruppen som ikke fikk munnstell (16\%), mot 14 $(7 \%)$ av dem som fikk $(\mathrm{p}<0,01)$.

Resultater som disse gir indirekte holdepunkter for at også oral dekontaminering av munnhulen med klorheksidin, som er langt mindre ressurskrevende enn mekanisk munnstell, kan gi tilsvarende gode resultater. Siden midlet har få og milde bivirknin- ger og bakteriell resistens ikke er noe stort problem, anser vi at bruk på indikasjoner som ikke er godt vitenskapelig dokumentert, som influensa, kan forsvares. Dette kan være særlig aktuelt hos personer som tilhører risikogruppene for å få lungekomplikasjoner, slik som pasienter med kronisk hjertesykdom og/eller lungesykdom og pasienter over $60-70$ år.

\section{Praktisk bruk}

Generelt kan det være berettiget å benytte klorheksidin i situasjoner der det er vanskelig eller umulig å oppnå god munnhygiene. Midlet kan enten brukes sammen med eller som et alternativ til mekanisk rensing og munnpleie. Studiene med oral applikasjon av klorheksidin viser stor variasjon mellom behandlingsrutinene, både hva angår konsentrasjon $(0,1-2 \%)$, applikasjonsteknikk og hyppighet. Det er usikkert hvilke regimer som er optimale ved de forskjellige indikasjoner. Et forslag til praktisk bruk av klorheksidin fremgår av ramme 1 .

\section{Oppgitte interessekonflikter: Ingen}

\section{Litteratur}

1. Bonesvoll P. Oral pharmacology of chlorhexidine. J Clin Periodontol 1977; 4: 49-65.

2. DeRiso AJ, Ladowski JS, Dillon TA et al. Chlorhexidine gluconate $0.12 \%$ oral rinse reduces the incidence of total nosocomial respiratory infection and nonprophylactic systemic antibiotic use in patients undergoing heart surgery. Chest 1996; 109: $1556-61$.

3. Cahn EY, Ruest A, Meade MO et al. Oral decontamination for prevention of pneumonia in mechanically ventilated adults: systematic review and meta-analysis. BMJ 2007; 334: 889-99.

4. Segers P, Speekenbrink RG, Ubbink DT et al. Prevention of nosocomial infection in cardiac surgery by decontamination of the nasopharynx and oropharynx with chlorhexidine gluconate: a randomized controlled trial. JAMA 2006; 296: 2460-6.

5. Chlebicki MP, Safdar N. Topical chlorhexidine for prevention of ventilator-associated pneumonia: a meta-analysis. Crit Care Med 2007; 35: 595-602.

6. Milstone AM, Passaretti CL, Perl TM. Chlorhexidine: expanding the armamentarium for infection control and prevention. Clin Infect Dis 2008; 46: 274-81.

7. Rindom-Schiøtt C, Löe H, Briner WW. Two year oral use of chlorhexidine in man. IV. Effect on various medical parameters. J Periodontal Res 1976: 11: 158-64

8. Batra R, Cooper BS, Whiteley $C$ et al. Efficacy and limitation of a chlorhexidine-based decolonization strategy in preventing transmission of methicillinresistant Staphylococcus aureus in an intensive care unit. Clin Infect Dis 2010; 50: $210-7$

9. Wip C, Napolitano L. Bundles to prevent ventilatorassociated pneumonia: how valuable are they? Curr Opin Infect Dis 2009; 22: 159-66.

10. Langslet A, Olsen I, Lie SO et al. Chlorhexidine treatment of oral candidiasis in seriously diseased children. Acta Pædiatr Scand 1974; 63: 809-11.

11. Bernstein D, Schliff G, Echler $G$ et al. In vitro virucidal effectiveness of a $0.1 \%$-chlorhexidine gluconate mouthrinse. J Dent Res 1990; 69: 874-6.

12. Yoneyama T, Yoshida M, Ohrui T et al. Oral care reduces pneumonia in nursing homes. J Am Geriatr Soc 2002; 50: 430-3.

Manuskriptet ble mottatt 24.11. 2009 og godkjent 27.7. 2010. Medisinsk redaktør Petter Gjersvik. 